\title{
Phenotypic and genotypic characteristics associated with biofilm formation in clinical isolates of atypical enteropathogenic Escherichia coli (aEPEC) strains
}

\author{
Heloisa H Nascimento ${ }^{1}$, Lucas EP Silva ${ }^{1}$, Renata T Souza ${ }^{1}$, Neusa P Silva ${ }^{2}$ and Isabel CA Scaletsky ${ }^{1 *}$
}

\begin{abstract}
Background: Biofilm formation by enteropathogenic Escherichia coli (EPEC) have been recently described in the prototype typical EPEC E2348/69 strain and in an atypical EPEC 055:H7 strain. In this study, we sought to evaluate biofilm formation in a collection of 126 atypical EPEC strains isolated from 92 diarrheic and 34 nondiarrheic children, belonging to different serotypes. The association of biofilm formation and adhesin-related genes were also investigated.

Results: Biofilm formation occurred in 37 (29\%) strains of different serotypes, when the assays were performed at $26^{\circ} \mathrm{C}$ and $37^{\circ} \mathrm{C}$ for $24 \mathrm{~h}$. Among these, four strains (A79, A87, A88, and A111) formed a stronger biofilm than did the others. The frequency of biofilm producers was higher among isolates from patients compared with isolates from controls (34.8\% vs 14.7\%; $P=0.029$ ). An association was found between biofilm formation and expression of type 1 fimbriae and curli $(P<0.05)$. Unlike the previously described aEPEC O55:H7, one aEPEC 0119:HND strain (A111) formed a strong biofilm and pellicle at the air-liquid interface, but did not express curli. Transposon mutagenesis was used to identify biofilm-deficient mutants. Transposon insertion sequences of six mutants revealed similarity with type 1 fimbriae (fimC, fimD, and fimH), diguanylate cyclase, ATP synthase F1, beta subunit (atpD), and the uncharacterized YjiC protein. All these mutants were deficient in biofilm formation ability.

Conclusion: This study showed that the ability to adhere to abiotic surfaces and form biofilm is present in an array of aEPEC strains. Moreover, it seems that the ability to form biofilms is associated with the presence of type 1 fimbriae and diguanylate cyclase. Characterization of additional biofilm formation mutants may reveal other mechanisms involved in biofilm formation and bring new insights into aEPEC adhesion and pathogenesis.
\end{abstract}

Keywords: Enteropathogenic Escherichia coli, Biofilm formation, Type 1 pili

\section{Background}

Enteropathogenic Escherichia coli (EPEC) is an important cause of infantile diarrhea, particularly in developing countries [1]. EPEC causes protracted and chronic diarrhea, and the severity of this disease may require extensive hospitalization [2-4]. The majority of EPEC isolates belong to classic serotypes derived from 12 classical O serogroups (O26, O55, O86, O111, O114, O119, O125, O126, O127, O128, O142, and O158) [5,6]. A key characteristic of

\footnotetext{
* Correspondence: scaletskyunifesp@gmail.com

${ }^{1}$ Departamento de Microbiologia, Imunologia e Parasitologia, Universidade Federal de São Paulo, Rua Botucatu, 862, 3 andar, 04023-062 São Paulo, Brazil Full list of author information is available at the end of the article
}

EPEC strains is the ability to intimately attach to intestinal epithelial cells and form attaching and effacing (AE) lesions. These lesions are characterized by the destruction of the microvilli and the rearrangement of the cytoskeleton, culminating in a pedestal-like structure at the site of bacterial contact [7]. The AE genes are localized to the locus for enterocyte effacement (LEE) and encode intimin, a type III secretion system, secreted proteins (Esp) and the translocated intimin receptor [8-10]. Another EPEC characteristic is the formation of microcolonies on cell monolayers "in vitro", a pattern known as localized adherence (LA) [11]. EPEC forms microcolonies on cultured epithelial

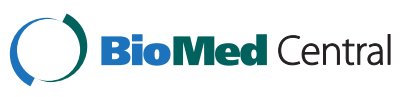


cells, cultures of pediatric small intestinal tissue, and biopsy samples from EPEC patients [12,13].

"Typical" EPEC (tEPEC) also contains the EPEC adherence factor (EAF) plasmid [14], which carries genes encoding a regulator (per) [15] and the bundle-forming pili (BFP) [16] that mediates LA to epithelial cells. EPEC strains, lacking the EAF plasmid are deprived of BFP, and have been designated "atypical" EPEC (aEPEC) [17]. aEPEC strains can still adhere to HEp-2 cells in a localized adherence-like pattern (LAL), forming loose bacterial microcolonies [18]. Recent epidemiological studies indicate that aEPEC is more prevalent than tEPEC in both developed and developing countries [1].

The aEPEC strains are genetically related to the enterohemorrhagic E. coli (EHEC), and both are considered emerging pathogens [19]. Some previous studies showed that certain EHEC strains have the abilities to attach, colonize, and form biofilm on various surfaces [20-24]. Some adhesins such as type 1 pilus (T1P), flagella, HCP ("hemorrhagic coli pilus"), curli, antigen 43 (Ag43), calcium-binding antigen 43 homologue (Cah), and autotransporter protein of EHEC (EhaA) have been implicated in the formation of microcolonies and biofilms [20-24]. Even though EPEC form microcolonies and causes persistent infections, very little is known regarding biofilm formation by EPEC strains, and their survival outside the host.

Recently, Moreira et al. [25] published the first description of biofilm formation by the prototype tEPEC E2348/ 69 (O127:H6) strain. These researchers found that adhesive structures, such as type 1 fimbriae, Ag43, BFP, and EspA, were expressed during the initial stages of biofilm development. More recently, Weiss-Muszkat et al. [26] reported a multicellular behavior characterized by the formation of a robust biofilm on an abiotic surface at $26^{\circ} \mathrm{C}$, but not at $37^{\circ} \mathrm{C}$, a dense pellicle at the air-liquid interface and a red, dry, and rough (rdar) morphotype in one O55: H7 aEPEC strain. Transposon mutagenesis analysis identified curli fibers and the $\mathrm{Crl}$ regulator as important participants in the formation of all three types of biofilms. The aim of this study was to evaluate the capacity of biofilm formation in a collection of 126 aEPEC strains isolated from diarrheic and nondiarrhiec children. The presence of adhesins related to biofilm formation and the association of biofilm formation and these adhesins were also investigated.

\section{Results and discussion}

A total of 126 EPEC strains isolated from 92 children with diarrhea and 34 asymptomatic controls were examined for the capacity of biofilm formation. As shown in Table 1, biofilm formation occurred in 37 (29.4\%) of strains of different serotypes after $24 \mathrm{~h}$ of incubation at $26^{\circ} \mathrm{C}$ and $37^{\circ} \mathrm{C}$. The frequency of biofilm producers was higher among isolates from patients compared to isolates from controls
Table 1 Biofilm formation in 126 clinical isolates of aEPEC strains

\begin{tabular}{cccc}
\hline Serotype & \multicolumn{3}{c}{ No. of strains (total/biofilm producers) } \\
\cline { 2 - 4 } & Patients & Controls & Total \\
\hline EPEC serotypes & & & \\
O26:H11;HND & $9 / 2$ & $1 / 0$ & $10 / 2$ \\
O55:HND & $4 / 1$ & $1 / 0$ & $5 / 1$ \\
O111:NM & $2 / 1$ & $2 / 1$ & $4 / 2$ \\
O114:NM & 0 & $1 / 0$ & $1 / 0$ \\
O119:H2;HND & $9 / 4$ & $1 / 0$ & $10 / 4$ \\
O125:HND & 0 & $1 / 0$ & $1 / 0$ \\
O126:NM & $1 / 1$ & 0 & $1 / 1$ \\
O127:NM;H40 & $4 / 2$ & $1 / 0$ & $5 / 2$ \\
O128:NM & $2 / 0$ & 0 & $2 / 0$ \\
O142:NM;H2 & $10 / 1$ & 0 & $10 / 1$ \\
Non-EPEC serotypes ${ }^{\mathrm{b}}$ & $23 / 5$ & $12 / 2$ & $35 / 7$ \\
ONT:H18/NM; HND & $28 / 15$ & $14 / 2$ & $42 / 17$ \\
Total & $92 / 32$ & $34 / 5^{c}$ & $126 / 37$
\end{tabular}

Biofilm assays were performed in 96-well polystyrene microtiter plates in Luria broth and incubated for $24 \mathrm{~h}$ at $26^{\circ} \mathrm{C}$ and $37^{\circ} \mathrm{C}$.

b4:HND; O15:HND O33:H6; O35:H19; O37:HND; O49:HND; O61:HND; O63:HND; O79:HND; O85:H40; O96:HND; O98:HND; O101:HNM; O103:HNM; O105:H7; O108:H31; O109:H54; O117:HND; 0132:HND; O141:HND; O1523H2; O156:H16; O157:NM; O167:H6; O169:H6; O175:HND.

$\mathrm{C}_{\mathrm{P}}<0.05$ (patients $\mathrm{x}$ controls).

(34.8\% vs $14.7 \% ; \mathrm{P}=0.029$ ). Most of the biofilmproducing strains formed biofilms on an abiotic surface at $26^{\circ} \mathrm{C}$ (Figure $1 \mathrm{~A}$ ), but not at $37^{\circ} \mathrm{C}$ (Figure $1 \mathrm{~B}$ ). Among these, four strains (A79, A87, A88, and A111) formed a stronger biofilm than did the others.

As shown in Table 2, the fimA/fimH genes were identified in 27 (73\%) strains, and the expression of type 1 fimbriae, was identified in all of them by MSHA assays. The genes related to curli ( $\operatorname{csgA}$ and $c r l$ ) were identified in 17 (45.9\%) strains, and all of them expressed curli as judged by characteristic red-colonies formed on CR agar plates. In addition, 18 of strains formed a thick pellicle at the airliquid interface at $26^{\circ} \mathrm{C}$ and $37^{\circ} \mathrm{C}$. The flagella gene $(f l i C)$ was identified in $11(29.8 \%)$ strains. The genes related to the autotransporter proteins Ag43 $(f l u)$, Cah (cah), and EhaA (ehaA) occurred in 9 (24.3\%), 7 (18.9\%), 5 (13.5\%) strains, respectively. The gene $h c p A$ was identified in two strains.

In attempt to identify genes potentially involved in biofilm formation, we selected one strong biofilm producer, but curli-negative, strain A111 of serotype O119:HND for mutagenesis. Like a previously described aEPEC O55:H7 strain, the A111 strain formed a strong biofim on an abiotic surface at $26^{\circ} \mathrm{C}$, but not at $37^{\circ} \mathrm{C}$, and a dense pellicle at the air-liquid interface (Figure 2). We generated a transposon library in the A111 strain using the EZ::TN $<$ R6Kyori/ KAN-2 $>$ Tnp transposome which confers resistance to 


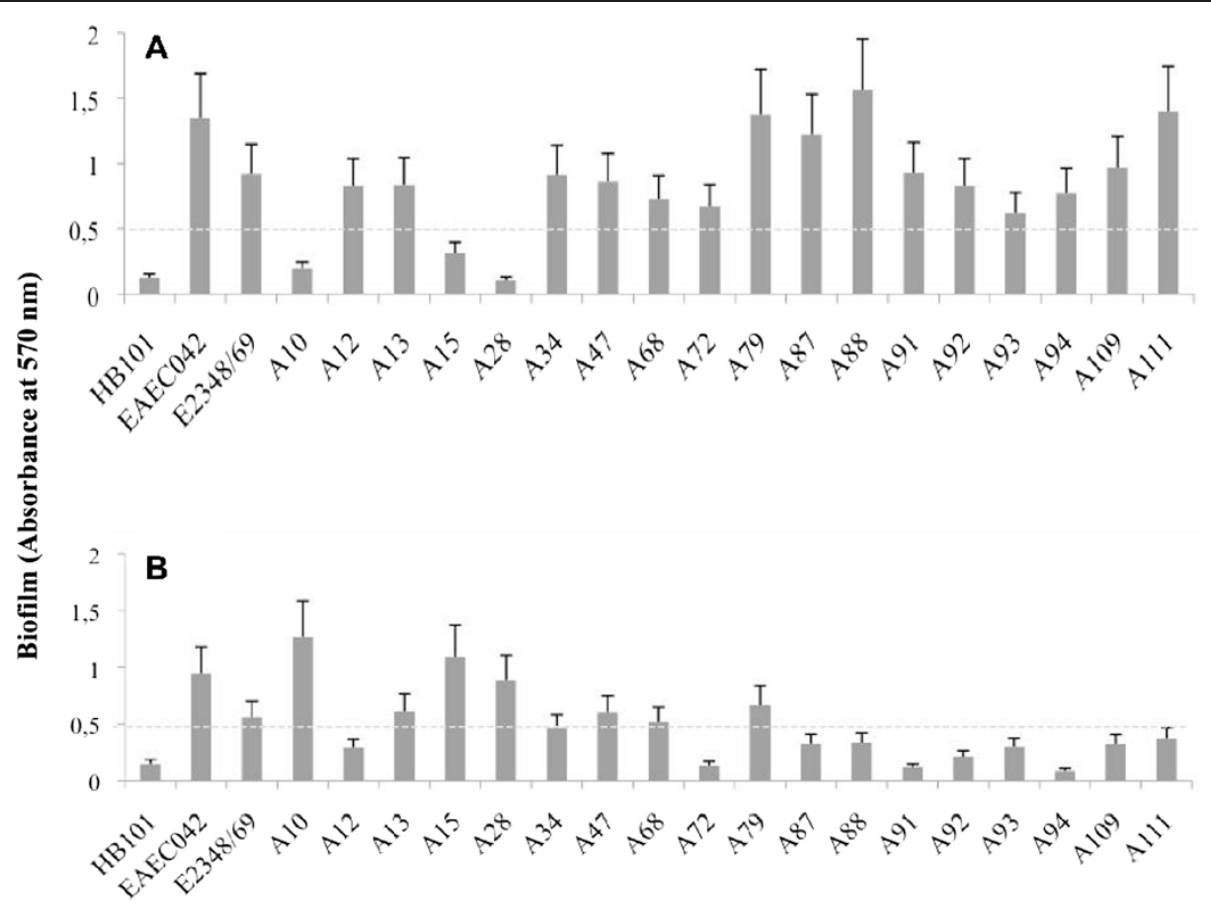

Figure 1 Biofilm formation on 96-well polystyrene microtiter plates by representative biofilm-producing aEPEC strains. Strains were incubated in $L B$ broth for $24 \mathrm{~h}$ at $26^{\circ} \mathrm{C}(\mathbf{A})$ and $37^{\circ} \mathrm{C}(\mathbf{B})$, and classified as biofilm producers when $\mathrm{OD}_{570}$ was higher than the $E$. coli $\mathrm{HB} 101$ strain mean value $\left(\mathrm{OD}_{570} \leq 0.5\right)$. Data are from a representative experiment with three replicates. The bars represent the standard deviation.

kanamycin and screened the mutants for their capacity to produce biofilm. Among the 1,165-transposon mutants screened, eight biofilm deficient mutants were identified and compared to the wild type strain. All of them were deficient in their biofilm formation ability and did not form a pellicle at the air-liquid interface (data not shown). Identification of the transposon insertion sites was performed using PCR and sequence analysis. The DNA sequences of the mutants revealed similarity with type 1 fimbriae (three mutants; fimC, fimD, and fimH), diguanylate cyclase (one mutant, YP_006105849.1), ATP synthase F1, beta subunit (one mutant; atpD), and the uncharacterized YjiC protein (one mutant; YP_002394414.1). In two mutants the insertion site was too short for analysis.

This study showed that the ability to adhere to abiotic surfaces and form biofilm at low temperature is present in an array of aEPEC strains, and not restricted to a particular set of serotypes. In addition, our case control analysis showed an association between the biofilmformation ability and diarrhea. These findings suggest that biofilm formation may play a role in the pathogenesis of some aEPEC strains.

A varied distribution of genes related to fimbrial and afimbrial adhesins reported in the literature to be associated with biofilm formation was identified among aEPEC strains. Recently, it has been shown that aEPEC strains harbor several pilus operons that could favor host colonization and environment survival [27]. In agreement with these findings, in our study, several adhesin genes were detected in most of the biofilm-producing strains. Interestingly, we observed an association between fimA/fim $H$ genes and biofilm formation. Of the 37 biofilm producers, 27 (73\%) carried the fimA/fimH genes versus 49 (55\%) of 89 nonbiofilm producers $(\mathrm{P}=0.016)$. In addition, the curli genes, $\operatorname{csg} A$ and $c r l$ were found in 17 (46\%) biofilm producers vs 28 (31\%) non-biofilm producers $(\mathrm{P}=0.041)$. No association was found between $f l i C$, flu, cah, ehaA, or hcpA genes.

A recent study reported that the ability of an EPEC strain of serotype $\mathrm{O} 55: \mathrm{H} 7$ to produce biofilm at low temperature $\left(26^{\circ} \mathrm{C}\right)$ was associated with curli [26]. In contrast, the A111 strain belonging to O119:HND formed a strong biofilm at $26^{\circ} \mathrm{C}$ pellicle at the air-liquid interface, but did not produce a red color on agar plates containing Congo red, implying that it does not produce curli. Three out of the six Tn5 mutants analyzed had insertions in genes associated with type 1 fimbriae. It seems that, in this particular strain, type 1 fimbriae plays an important role in the interaction with abiotic surfaces, as the inactivation of the fimC, fimD, and fimH genes, significantly reduced its capacity to form biofilm and pellicle. In agreement with our findings, it has been recently reported that a mutation in the fimA gene of an aEPEC strain drastically affected its ability to form biofilm on plastic surface [28].

In addition, in one mutant, the inactivation of diguanylate cyclase also impaired biofilm formation. Cellular levels of c-di-GMP, a ubiquitous second messenger in 
Table 2 Phenotypic and genotypic characteristics of aEPEC biofilm-producing strains

\begin{tabular}{|c|c|c|c|c|c|c|c|c|c|c|c|c|c|c|c|c|}
\hline \multirow[t]{3}{*}{ Strain } & \multirow[t]{3}{*}{ Serotype } & \multirow[t]{3}{*}{ Source } & \multicolumn{4}{|c|}{ Biofilm formation } & \multicolumn{3}{|c|}{ Expression of adhesins } & \multicolumn{7}{|c|}{ Adhesin gene sequences } \\
\hline & & & \multicolumn{2}{|c|}{ Abiotic surface } & \multicolumn{2}{|c|}{$\overline{\text { Air-liquid interface }}$} & \multicolumn{2}{|c|}{ Curli } & \multirow[t]{2}{*}{$\mathrm{T} \mathrm{F}^{\mathrm{a}}$} & \multirow[b]{2}{*}{$\operatorname{fim} A$} & \multirow[b]{2}{*}{ flic } & \multirow[b]{2}{*}{$\operatorname{csg} A$} & \multirow[b]{2}{*}{$h c p A$} & \multirow[b]{2}{*}{ flu } & \multirow[b]{2}{*}{$c a h$} & \multirow[b]{2}{*}{ ehaA } \\
\hline & & & $26^{\circ} \mathrm{C}$ & $37^{\circ} \mathrm{C}$ & $26^{\circ} \mathrm{C}$ & $37^{\circ} \mathrm{C}$ & $26^{\circ} \mathrm{C}$ & $37^{\circ} \mathrm{C}$ & & & & & & & & \\
\hline A91 & O15:HND & Patient & + & - & + & - & + & + & + & + & - & + & - & - & - & - \\
\hline A72 & O26:HND & Patient & + & - & + & - & - & + & - & - & + & + & - & + & - & - \\
\hline A132 & O26:HND & Patient & + & - & + & - & - & - & + & + & + & - & - & + & - & - \\
\hline A113 & O55:HND & Patient & + & - & + & - & - & - & + & + & + & - & + & - & - & - \\
\hline A15 & $\mathrm{O} 85: \mathrm{H} 40$ & Patient & - & + & - & - & - & + & + & + & - & + & - & - & + & + \\
\hline A28 & O103:NM & Patient & - & + & - & - & - & + & + & + & + & + & - & - & + & - \\
\hline A4 & O111:NM & Control & - & + & - & - & - & + & + & + & - & + & - & - & - & + \\
\hline $\mathrm{A} 12$ & O111:NM & Patient & + & - & - & + & - & - & + & + & - & - & - & + & - & - \\
\hline A60 & O119:H2 & Patient & + & + & - & + & - & - & + & + & - & - & - & - & - & - \\
\hline A67 & $\mathrm{O} 119: \mathrm{H} 2$ & Patient & - & + & - & + & - & - & + & + & - & - & - & - & - & - \\
\hline A93 & O119:HND & Patient & + & - & + & + & - & - & + & + & - & - & - & + & - & - \\
\hline A111 & O119:HND & Patient & + & - & + & + & - & - & + & + & - & - & - & - & - & - \\
\hline $\mathrm{A} 13$ & O126:NM & Patient & + & + & - & - & - & - & + & + & - & - & - & + & - & - \\
\hline A5 & O127:H40 & Patient & + & + & + & - & + & - & - & - & - & + & - & - & - & - \\
\hline A34 & O127:NM & Patient & + & - & - & - & - & - & - & - & + & - & - & - & - & + \\
\hline A47 & O141:HND & Control & + & + & - & - & - & + & - & - & - & + & - & - & + & - \\
\hline $\mathrm{A} 11$ & O142:NM & Patient & + & + & - & - & - & - & - & - & - & - & - & + & - & - \\
\hline A87 & O153:H2 & Patient & + & - & + & + & + & + & + & + & + & + & - & - & - & - \\
\hline A36 & O157:HND & Control & + & + & + & - & - & - & - & - & - & - & - & - & + & - \\
\hline A92 & O167:H6 & Patient & + & - & + & - & + & - & + & + & - & + & - & - & - & - \\
\hline $\mathrm{A} 10$ & ONT:HND & Patient & - & + & - & - & - & - & + & + & - & - & - & + & - & - \\
\hline $\mathrm{A} 20$ & ONT:HND & Patient & + & + & - & - & - & + & + & + & - & + & - & - & - & - \\
\hline $\mathrm{A} 22$ & ONT:HND & Patient & - & + & - & - & - & - & + & + & - & - & - & - & - & - \\
\hline A39 & ONT:NM & Patient & + & + & - & - & - & + & + & + & - & + & - & - & - & - \\
\hline A48 & ONT:HND & Control & + & - & - & - & - & + & - & - & - & + & - & - & + & - \\
\hline A49 & ONT:HND & Patient & - & + & + & - & + & + & - & - & - & + & - & - & - & - \\
\hline A68 & ONT:HND & Patient & + & + & + & - & + & + & + & + & - & + & - & - & + & - \\
\hline A73 & ONT:HND & Control & + & - & - & - & - & - & + & + & + & - & - & - & - & - \\
\hline A79 & ONT:HND & Patient & + & + & + & - & - & - & + & + & + & - & - & - & - & - \\
\hline A88 & ONT:HND & Patient & + & - & + & + & - & - & + & + & - & - & - & - & - & - \\
\hline A94 & ONT:HND & Patient & + & - & - & - & - & - & - & - & - & - & - & - & + & - \\
\hline A98 & ONT:HND & Patient & + & - & - & - & - & + & + & + & + & + & - & - & - & + \\
\hline A99 & ONT:HND & Patient & + & + & - & + & - & - & + & + & + & - & - & - & - & + \\
\hline A112 & ONT:HND & Patient & + & + & + & - & - & - & + & + & - & - & - & - & - & - \\
\hline A146 & ONT:HND & Patient & + & + & + & + & + & + & + & + & - & + & - & + & - & - \\
\hline A109 & ONT:HND & Patient & + & - & + & + & + & - & - & - & - & + & - & - & - & - \\
\hline A157 & ONT:HND & Patient & + & + & + & + & - & - & + & + & + & - & + & + & - & - \\
\hline \multicolumn{3}{|c|}{ Total no. of strains $(n=37)$} & 30 & 21 & 18 & 11 & 8 & 14 & 27 & 27 & 11 & 17 & 2 & 9 & 7 & 5 \\
\hline
\end{tabular}

${ }^{\mathrm{a}} \mathrm{T} 1 \mathrm{~F}$, type 1 fimbriae.

bacteria, are controlled through the opposing activities of diguanylate cyclases and phosphodiesterases. Cyclicdi-GMP antagonistically controls motility and virulence of single, planktonic cells on one hand, and cell adhesion and persistence of multicellular communities on the other [29]. 

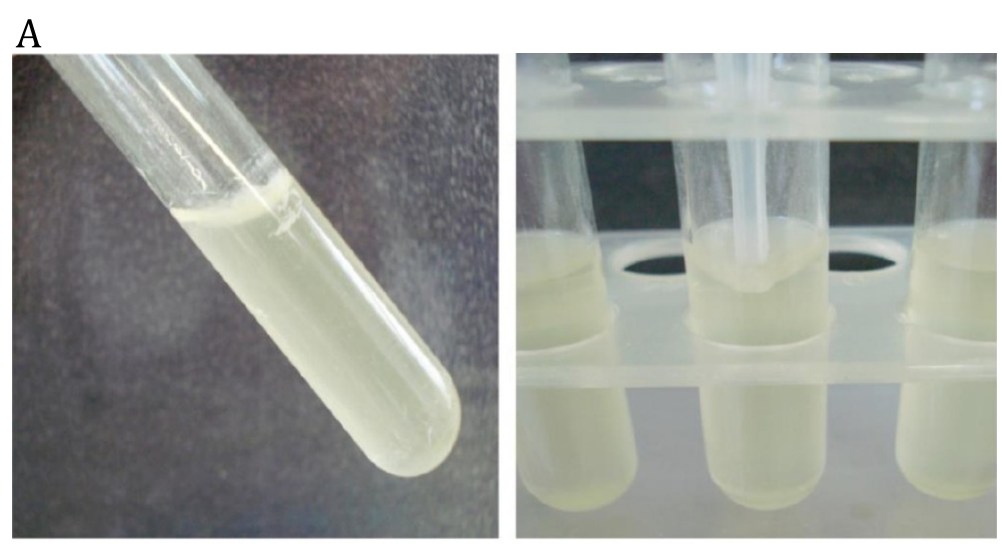

$\mathrm{B}$
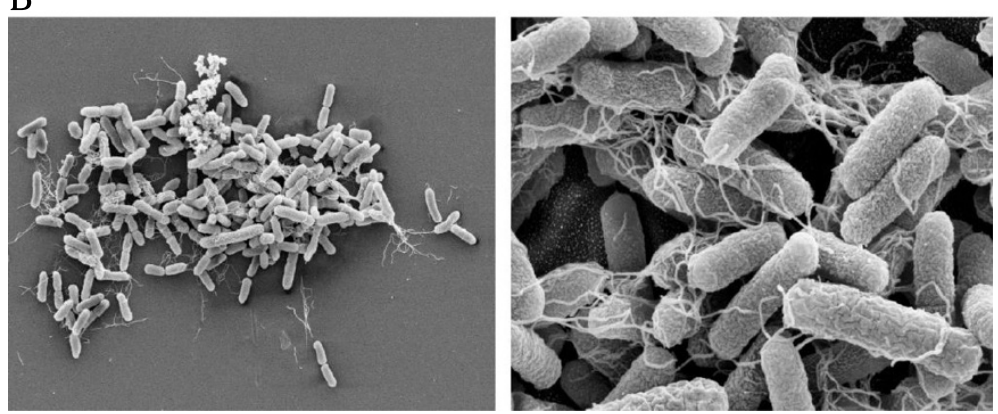

Figure 2 Biofilm-formation ability of the A111 curli-negative strain. A - Pellicle formation at the air-liquid interface; $\mathbf{B}$ - SEM micrographs of the biofilm formed on glass coverslips.

\section{Conclusion}

This is the first study showing that the ability to adhere to abiotic surfaces and form biofilm is present in an array of aEPEC strains, and is not restricted to a particular set of serotypes. Our data suggest that type 1 fimbriae and diguanylate cyclase may be involved in aEPEC biofilm formation. Characterization of additional biofilm deficient mutants may reveal other mechanisms involved in biofilm formation and bring new insights into aEPEC pathogenesis.

\section{Methods}

\section{Bacterial strains}

The 126 aEPEC strains examined in this study belonged either to EPEC $(n=49)$ or non EPEC serotypes $(n=77)$, and were isolated during an epidemiological study of acute diarrhea in children under 2 years of age; the study was conducted in several cities of Brazil from 1999 through 2004 [30]. In the study, 1,102 stool specimens were obtained from children with diarrhea, presenting at the emergency room of public hospitals in seven cities representing different regions of Brazil, and 647 randomly selected children without any gastrointestinal symptoms from the same hospitals were studied. All strains were investigated for the presence of enteric pathogens such as diarrheagenic E. coli, Shigella, Salmonella, Vibrio, Campylobacter, Giardia lamblia, Cryptosporidium, and rotavirus. Atypical EPEC strains isolated as the only pathogen in stool samples were serotyped with specific antisera O1-O175 and H1-H56 acquired commercially (from the Universidad de Santiago de Compostela; Lugo, Spain). One isolate per subject was stored at $-70^{\circ} \mathrm{C}$ in Luria Bertani broth (LB) with $15 \%$ glycerol.

\section{Ethics statement}

The study was approved by the ethics committee of the Universidade Federal de São Paulo, Brazil. Stool samples were obtained with the written informed consent from the parents or guardians of the children with or without diarrhea.

\section{Biofilm formation assay}

Biofilm assays were performed in triplicate using LB medium in 96-well polystyrene microtiter plates as previously described [26]. Briefly, strains were grown overnight at $37^{\circ} \mathrm{C}$ in LB. The optical density at $600 \mathrm{~nm}\left(\mathrm{OD}_{600}\right)$ of the culture was adjusted to 1.0 (corresponding to ca. $10^{8} \mathrm{CFU} / \mathrm{ml}$ ). The cultures were then diluted 1:10 in fresh LB and used to inoculate three individual wells $(200 \mu \mathrm{l}$ per well). Plates were incubated statically at $26^{\circ} \mathrm{C}$ or $37^{\circ} \mathrm{C}$ for $24 \mathrm{~h}$. Following these incubation periods, plates were washed three times with $250 \mu \mathrm{l} /$ well of sterile phosphatebuffered saline $(\mathrm{PBS})$. The plates were dried $\left(26^{\circ} \mathrm{C}\right.$ for 
$15 \mathrm{~min}$ ), and each well was stained with $200 \mu \mathrm{l} 0.1 \%$ crystal violet for $20 \mathrm{~min}$. The $\mathrm{OD}_{570}$ values were determined in a microplate reader after solubilization of the dye with 95\% ethanol (200 $\mu \mathrm{l}$ per well). The ability of aEPEC strains to form biofilm on abiotic surfaces was assessed by comparison with the standard biofilm producing enteroaggregative E. coli 042 strain (EAEC) and a non-biofilm forming strain (E. coli HB101). Strains were classified as biofilm producers when $\mathrm{OD}_{570}$ was higher than the $E$. coli HB101 strain mean value $\left(\mathrm{OD}_{570} \leq 0.5\right)$. The biofilm producer strains were also subdivided into strong $\left(\mathrm{OD}_{570} \geq\right.$ $1.0)$ and weak $\left(\mathrm{OD}_{570}>0.5<1\right)$ in comparison to the result of the EAEC 042 strain mean value $\left(\mathrm{OD}_{570} \geq 1.0\right)$.

Biofilms were also analyzed by scanning electron microscopy (SEM). For SEM observations, coverslips in 24 well plates were used as adhesion surface. After incubation, the coverslips were washed three times with PBS and immersed in $2.5 \%$ glutaraldehyde in $0.1 \mathrm{M}$ imidazole buffer ( $\mathrm{pH}$ 7.0) for $2 \mathrm{~h}$ at room temperature. The preparations were then dehydrated in a graded series of ethanol solutions $(50 \%, 80 \%$ and absolute), dried at critical point using $\mathrm{CO}_{2}$ as the transition fluid, and sputtercoated with gold.

\section{Pellicle formation}

Strains were grown overnight in $\mathrm{LB}$ at $37^{\circ} \mathrm{C}$ and $5 \mathrm{ml}$ was transferred into $4 \mathrm{ml} \mathrm{LB}$ in $15-\mathrm{ml}$ glass tubes. After $48 \mathrm{~h}$ at $26^{\circ} \mathrm{C}$ or $37^{\circ} \mathrm{C}$ or the formation of biofilm (pellicle) at the air-liquid interface was visually observed and photographed with a digital camera.

\section{Detection of type 1 fimbriae and curli}

Type 1 fimbriae expression was detected by the mannosesensitive hemagglutination assay (MSHA) of guinea pig erythrocytes based on the method of Evans et al. [31] with some modifications. Bacterial suspensions $\left(\sim 3.0 \times 10^{8}\right.$ cells/ $\mathrm{ml}$ ) in PBS, prepared after growth in LB broth at $37^{\circ} \mathrm{C}$ for $18 \mathrm{~h}$, were mixed with guinea pig red blood cells at room temperature in the presence or absence of 1\% D-mannose. Curli production was evaluated on YESCA agar plates containing $40 \mathrm{mg} / \mathrm{l}$ of Congo Red (CR) and incubated for $24 \mathrm{~h}$ at $26^{\circ} \mathrm{C}$ or $37^{\circ} \mathrm{C}$. Colony morphology was scored according to morphotypes previously described for S. typhimurium: red colonies are curli positive and white colonies, curli negative [32]. E. coli HB101 strain was used as a curli negative control.

\section{PCR assays}

Strains were probed by PCR for the presence of fimA and fimH (type 1 fimbriae) [33,34], fliC (flagella) [35], csgA (curli structural subunit) [36], hcpA (hemorrhagic coli pilus) [37], flu (antigen 43) [38], cah (calcium-binding antigen 43 homologue) [39], and ehaA (Eha passenger domain) [40] genes.

\section{Transposon mutagenesis and genetic analysis}

The aEPEC A111 strain was mutagenized with the EZ:: TN $<$ R6Kyori/KAN-2 > Tnp transposome (Epicentre) according manufacturer's instructions. Briefly, electrocompetent aEPEC cells were transformed with $1 \mu$ of the Tnp transposome. Transposon-inserted bacterial colonies that grew on LB agar plates containing kanamycin were screened for biofilm formation as described above. Genomic DNA of the biofilm deficient mutants was digested with EcoRI and self-ligated, and used for transformation of E. coli DH5 $\alpha \lambda$ pir. Rescued DNA plasmids were purified and sequenced using the transposonspecific primers R6KAN-2 RP-1 and KAN-2 FP-1 (Epicentre). DNA sequencing was performed at the Centro de Estudos do Genoma Humano-USP, São Paulo. Nucleotide sequence data were analyzed using SeqMan and MegAlign software and the BLAST tool (http://www. ncbi.nlm.nih.gov/BLAST).

\section{Nucleotide sequences and accession numbers}

The DNA sequences for the six mutants are availability in NCBI database under accession numbers KM044265KM044270, respectively.

\section{Competing interests}

The authors declare that they have no competing interests.

\section{Authors' contributions}

HHN and LEPS performed experiments and analyzed data. RTS participated in the sequence alignment and sequence submission. NPS and ICAS wrote the manuscript. All authors read and approved the final manuscript.

\section{Acknowledgments}

This study was supported by research grants from Fundação de Amparo a Pesquisa do Estado de São Paulo (FAPESP) and Conselho Nacional de Desenvolvimento Científico e Tecnológico (CNPq).

\section{Author details}

'Departamento de Microbiologia, Imunologia e Parasitologia, Universidade Federal de São Paulo, Rua Botucatu, 862, 3 andar, 04023-062 São Paulo, Brazil. Disciplina de Reumatologia, Universidade Federal de São Paulo, São Paulo, Brazil.

Received: 19 June 2013 Accepted: 4 July 2014

Published: 10 July 2014

\section{References}

1. Ochoa TJ, Contreras CA: Enteropathogenic Escherichia coli infection in children. Curr Opin Infect Dis 2011, 24:478-483.

2. Hill SM, Phillips AD, Walker-Smith JA: Enteropathogenic Escherichia coliand life threatening chronic diarrhea. Gut 1991, 32:154-158.

3. Rothbaum R, McAdams AJ, Giannella R, Partin JC: A clinicpathologic study of enterocyte-adherent Escherichia coli: a cause of protracted diarrhea in infants. Gastroenterology 1982, 83:441-454.

4. Fagundes Neto U, Scaletsky IC: Escherichia coli infections and malnutrition. Lancet 2000, 356(Suppl):s27.

5. WHO: Programme for Control of Diarrhoeal Diseases, Manual for laboratory investigation of acute enteric infections. Geneva: World Health Organization; 1987.

6. Nataro JP, Kaper JB: Diarrheagenic Escherichia coli. Clin Microbiol Rev 1998, 11:142-201.

7. Moon HW, Whipp SC, Argenzio RA, Levine MM, Gianella RA: Attaching and effacing activities of rabbit and human enteropathogenic Escherichia coli in pig and rabbit intestines. Infect Immun 1983, 41:1340-1351. 
8. Jerse $A E, Y u$ J, Tall BD, Kaper JB: A genetic locus of enteropathogenic Escherichia coli necessary for the production of attaching and effacing lesions on tissue culture cells. Proc Natl Acad Sci U S A 1990, 87:7839-7843.

9. Jarvis KG, Girón JA, Jerse AE, McDaniel TK, Donnenberg MS, Kaper JB: Enteropathogenic Escherichia coli contains a putative type III secretion system necessary for the export of proteins involved in attaching and effacing lesion formation. Proc Natl Acad Sci U S A 1995, 92:7996-8000.

10. Kenny B, DeVinney R, Stein M, Finlay BB: Enteropathogenic E coli (EPEC) transfers its receptor for intimate adherence into mammalian cells. Cell 1997, 91:511-520.

11. Scaletsky ICA, Silva MLM, Trabulsi LR: Distinctive patterns of adherence of enteropathogenic Escherichia coli to HeLa cells. Infect Immun 1984, 45:534-536.

12. Bieber D, Ramer SW, Wu CY, Murray WJ, Tobe T, Fernandez R, Schoolnik GK: Type IV pili, transient bacterial aggregates, and virulence of enteropathogenic Escherichia coli. Science 1998, 280:2114-2118.

13. Hicks S, Frankel G, Kaper JB, Dougan G, Phillips AD: Role of intimin and bundle-forming pili in enteropathogenic Escherichia coli adhesion to pediatric intestinal tissue in vitro. Infect Immun 1998, 66:1570-1578.

14. Nataro JP, Baldini MM, Kaper JB, Black RE, Bravo N, Levine MM: Detection of an adherence fator of enteropathogenic Escherichia coli with a DNA probe. J Infect Dis 1985, 152:560-565.

15. Gómez-Duarte OG, Kaper JB: A plasmid-encoded regulatory region activates chromosome eaeA expression in enteropathogenic Escherichia coli. Infect Immun 1995, 63:1767-1776.

16. Girón JA, Ho AS, Schoolnik GK: An inducible bundle-forming pilus of enteropathogenic Escherichia coli. Science 1991, 254:710-713.

17. Kaper JB: Defining EPEC. Rev Microbio/ São Paulo 1996, 27:130-133.

18. Scaletsky ICA, Pedroso MZ, Oliva CAG, Carvalho RLB, Morais MB, Fagundes-Neto U: A localized adherence-like pattern as a second pattern of adherence of classic enteropathogenic Escherichia coli to HEp-2 cells that is associated with infantile diarrhea. Infect Immun 1999, 67:3410-3415.

19. Trabulsi LR, Keller R, Gomes TAT: Typical and atypical enteropathogenic Escherichia coli. Emerg Infect 2002, 8:508-513.

20. Cookson AL, Cooley WA, Woodward MJ: The role of type 1 and curli fimbriae of Shiga-toxin-producing Escherichia coli in adherence to abiotic surfaces. Int J Med Microbiol 2002, 292:195-205.

21. Danese PN, Pratt LA, Kolter R: Exopolysaccharide production is required for development of Escherichia coli K-12 biofilm architecture. J Bacteriol 2000, 182:3593-3596.

22. Pringent-Combaret C, Prensier G, Thi TT, Vidal O, Lejeune P, Dorel C: Developmental pathway for biofilm formation in curli-producing Escherichia coli strains: role of flagella, curli and colonic acid. Environ Microbiol 2000, 2:450-464.

23. Ryu JH, Bechaut LR: Biofilm formation by Escherichia coli 0157:H7 on stainless steel: effect of exopolysaccharide and curli production on its resistance to chlorine. Appl Environ Microbiol 2005, 71:247-254.

24. Schembri MA, Christiansen G, Klemm P: FimH-mediated autoaggregation of Escherichia coli. Mol Microbiol 2001, 41:1419-1430.

25. Moreira CG, Palmer K, Whiteley M, Sircili MP, Trabulsi LR, Castro AFP, Sperandio V: Bundle-forming pili and EspA are involved in biofilm formation by enteropathogenic Escherichia coli. J Bacteriol 2006, 188:3952-3961.

26. Weiss-Muzkat M, Shakh D, Zhou Y, Pinto P, Belausov E, Chapman MR, Sela S: Biofilm formation and multicellular behavior in Escherichia coli O55:H7, an atypical enteropathogenic strain. Appl Environ Microbiol 2010, 76:1545-1554.

27. Hernandes RT, Velsko I, Sampaio SC, Elias WP, Robins-Browne RM, Gomes TAT, Girón JA: Fimbrial adhesins produced by atypical enteropathogenic Escherichia coli strains. Appl Environ Microbiol 2011, 77:9391-8399.

28. Hernandes RT, De la Cruz MA, Yamamoto D, Girón JA, Gomes TAT: Dissection of the role of pili and type 2and type 3 secretion systems in adherence and biofilm formation of an atypical enteropathogenic Escherichia coli strain. Infect Immun 2013, 81:3793-3802.

29. Jenal U, Malone J: Mechanisms of cyclic-di-GMP signaling in bacteria. Annu Rev Genet 2006, 40:385-407

30. Scaletsky ICA, Aranda KR, Souza TB, Silva NP, Morais MB: Evidence of pathogenic subgroups among atypical enteropathogenic Escherichia coli strains. J Clin Microbiol 2009, 47:3756-3759.
31. Evans DJ, Evans DG, Dupont HL: Hemagglutination patterns of enterotoxigenic and enteropathogenic Escherichia coli determined with human, bovine, chicken, and guinea pig erythrocytes in the presence and absence of mannose. Infect Immun 1979, 23:336-346.

32. Römling U, Sierralt WD, Eriksson K, Normark S: Multicellular and aggregative behavior of Salmonella typhimurium strains is controlled by mutations in the agfD promoter. Mol Microbiol 1998, 28:249-264.

33. Welinder-Olsson C, Eriksson E, Kaijser B: Virulence genes in verocytotoxigenic Escherichia coli strains isolated from humans and cattle. APMIS 2005, 113:577-85.

34. Johnson JR, Stell AL: Extended virulence genotypes of Escherichia coli strains from patients with urosepsis in relation to phylogeny and host compromise. J Infect Dis 2000, 181:261-272.

35. Fields PI, Blom K, Hughes HJ, Helsel LO, Feng P, Swaminathan B: Molecular characterization of the gene encoding $\mathrm{H}$ antigen in Escherichia coli and development of a PCR-restriction fragment length polymorphism test for identification of Escherichia coli 0157:H7 and 0157:NM. J Clin Microbiol 1997, 35:1066-1070

36. Maurer JJ, Brown TP, Steffens WL, Thayler SG: The occurrence of ambient temperature-regulated adhesins, curli, and the temperature-sensitive hemagglutinin tsh among avian Escherichia coli. Avian Dis 1998, 42:106-118.

37. Xicohtncatl-Cortes J, Monteiro-Neto V, Ledesma MA, Jordan DM, Francetic O, Kaper JB, Puente JL, Girón JA: Intestinal adherente associated with type IV pili of enterohemorrhagic Escherichia coli 0157:H7. J Clin Invest 2007, 117:3519-3529.

38. Restieri C, Garriss G, Locas MC, Dozois CM: Autotransporter-encoding sequences are phylogenetically distributed among Escherichia coli clinical isolates and reference strains. Appl Environ Microbiol 2007, 73:1553-62.

39. Torres AG, Perna NT, Burland V, Ruknudin A, Blattner FR, Kaper JB: Characterization of Cah, a calcium-binding and heat-extractable autotransporter protein of enterohemorrhagic Escherichia coli. Mol Microbiol 2002, 45:951-966.

40. Wells TJ, Sherlock O, Rivas L, Mahajan A, Beatson SA, Torpdahl M, Webb R, Allsopp LP, Gobius KS, Gally DL, Schembri MA: EhaA is a novel autotransporter protein of enterohemorrhagic Escherichia coli 0157:H7 that contributes to adhesion and biofilm formation. Environ Microbiol 2008, 10:589-604.

\section{doi:10.1186/1471-2180-14-184}

Cite this article as: Nascimento et al:: Phenotypic and genotypic characteristics associated with biofilm formation in clinical isolates of atypical enteropathogenic Escherichia coli (aEPEC) strains. BMC Microbiology 2014 14:184.

\section{Submit your next manuscript to BioMed Central and take full advantage of:}

- Convenient online submission

- Thorough peer review

- No space constraints or color figure charges

- Immediate publication on acceptance

- Inclusion in PubMed, CAS, Scopus and Google Scholar

- Research which is freely available for redistribution 